American University Washington College of Law

Digital Commons @ American University Washington College of Law

Articles in Law Reviews \& Other Academic Journals

2008

Bosnia v. Serbia: Lessons from the Encounter of the International Court of Justice with the International Criminal Tribunal for the Former Yugoslavia

Rebecca Hamilton

Richard J. Goldstone

Follow this and additional works at: https://digitalcommons.wcl.american.edu/facsch_lawrev

Part of the Courts Commons, Evidence Commons, International Humanitarian Law Commons, International Law Commons, and the Legal History Commons 


\title{
Bosnia v. Serbia: Lessons from the Encounter of the International Court of Justice with the International Criminal Tribunal for the Former Yugoslavia
}

\author{
RICHARD J. GOLDSTONE AND REBECCA J. HAMILTON*
}

\begin{abstract}
This article uses the recent judgment of the ICJ in Bosnia v. Serbia to highlight the potential problems that arise when international courts have to adjudicate on overlapping situations. It describes the dispute between the ICJ and the ICTY on the appropriate legal standard for the attribution of state responsibility, and finds that the ICJ's approach in this case suggests that those keen to minimize the fragmentation of international law between adjudicative bodies should not overlook the need for consistency within those bodies. With regard to fact finding, this article raises serious concerns about the manner in which the ICJ relied on the ICTY's work. The decision of the ICJ not to demand crucial documents from Serbia is discussed and criticized. Based on its approach to fact finding in this case, doubts are raised as to whether the ICJ will ever hold a state responsible for genocide outside the parameters of the prior criminal convictions of individual perpetrators.
\end{abstract}

\section{Key words}

evidence; fact-finding; fragmentation of international law; genocide; International Court of Justice; International Criminal Tribunal for the former Yugoslavia

\section{INTRODUCTION}

The recent judgment of the International Court of Justice (ICJ) in the Case Concerning the Application of the Convention on the Prevention and Punishment of the Crime of Genocide (Bosnia and Herzegovina v. Serbia and Montenegro) ${ }^{\mathrm{I}}$ was a historic moment for the global community. The question before the ICJ was whether Serbia ${ }^{2}$ could be held responsible for genocide on the basis of atrocities committed in Bosnia and Herzegovina following the I 992 break-up of the former Yugoslavia. The case

Richard Goldstone is Mulligan Visiting Professor of Law at Fordham Law School, former Chief Prosecutor of the International Criminal Tribunals for the former Yugoslavia and Rwanda (e-mail: rgoldstone@iafrica.com). Rebecca J. Hamilton, J.D., M.P.P. (Harvard Law School; John F. Kennedy School of Government), is a former intern of the ICTY (e-mail: Rebecca_Hamilton@ post.harvard.edu). This article was submitted in August 2007.

I. Case Concerning the Application of the Convention on the Prevention and Punishment of the Crime of Genocide (Bosnia and Herzegovina v. Serbia and Montenegro), Judgment of 27 February 2007 (hereinafter Bosnia u. Serbia).

2. When the case began in I993 the respondent's name was the Federal Republic of Yugoslavia (FRY). FRY President Milošević was overthrown on 5 October 2000, and on 4 February 2003 the FRY's name changed to Serbia and Montenegro. However, on 2I May 2006 Montenegro declared its independence, and so by the time of the final judgment the respondent's name was Serbia. In the following article the respondent will be referred to as 'Serbia'. 
represented the first time that a court had adjudicated whether a sovereign state could be held responsible for genocide in the almost sixty years since the Convention on the Prevention and Punishment of the Crime of Genocide was unanimously approved by the General Assembly of the United Nations. ${ }^{3}$

The ICJ's I 7 I-page judgment is likely to generate a plethora of journal articles as legal scholars assess the long-term impact of the judgment on previously uncharted territories of international jurisprudence. In this respect, one of the most interesting issues arising from the case involves the challenges presented when different international courts have to adjudicate on overlapping factual situations.

The general issue of the fragmentation of international law has already been the topic of much legal writing, ${ }^{4}$ and the International Law Commission has conducted a working-group study on the potential for the fragmentation of jurisprudence with the proliferation of international adjudicative systems. ${ }^{5}$ In the arena of international criminal law this discussion came to prominence following the creation of the first ad hoc criminal tribunal, the International Criminal Tribunal for the former Yugoslavia (ICTY) in I 993, and is likely to remain a topical issue with the advent of the permanent International Criminal Court (ICC).

Given that the ICTY has now produced over a decade's worth of jurisprudence on the atrocities committed in the former Yugoslavia, the ICJ's Bosnia v. Serbia judgment makes for a particularly good study of the issues that can arise when an international court with one mandate has to adjudicate on a situation that an international court with a different mandate has already adjudicated on. The ICJ is the principal judicial organ of the United Nations, and its work involves disputes between states. By contrast the ICTY was created by the United Nations in order to establish individual criminal responsibility for the atrocities committed since I99I in the former Yugoslavia. The consequences of these differences in mandate and expertise come to the fore in Bosnia v. Serbia.

The overlap between the issues in Bosnia v. Serbia and the ICTY cases arises in terms of both the legal analysis and the fact-finding process. With respect to the former we look at the ICJ's legal test for the attribution of state responsibility, established in Military and Paramilitary Activities in and against Nicaragua (Nicaragua v. United States of America), ${ }^{6}$ and restated in Bosnia v. Serbia, ${ }^{7}$ as compared with the

3. Convention on the Prevention and Punishment of the Crime of Genocide, 9 December I 948, 78 UNTS 277 (hereinafter Genocide Convention).

4. The commentary on the question of fragmentation falls into two broad streams: those who view fragmentation as a chaos to be avoided; see, e.g., G. Guillaume, 'The Future of International Judicial Institutions,' (I995) 44 ICLQ 848, at 862 , and those who embrace it as a sign of the maturing of international law; see, e.g., M. Koskenniemi and P. Leino, 'Fragmentation of International Law? Post-modern Anxieties,' (2002) I5 LJIL 553, at 575-9. A middle ground has been pursued by ICJ President Rosalyn Higgins; see R. Higgins, 'A Babel of Judicial Voices? Ruminations from the Bench,' (2006) 55 ICLQ 79I (suggesting that commentators may have exaggerated the potential for fragmentation, as in her view the different international courts will seek common approaches wherever possible).

5. 'Conclusions of the Work of the Study Group on the Fragmentation of International Law: Difficulties Arising from the Diversification and Expansion of International Law, Yearbook of the International Law Commission (2006), available at http://untreaty.un.org/ilc/texts/instruments/english/draft\%20articles/I 9 2006.pdf.

6. Military and Paramilitary Activities in and against Nicaragua (Nicaragua v. United States of America), Merits, Judgment of 27 June I986, [I986] ICJ Rep. 392 (hereinafter Nicaragua), paras. I09-IIO, II5.

7. Bosnia v. Serbia, supra note I, paras. 39I, 399, 40I (affirming the legal tests established in Nicaragua). 
test proposed by the ICTY Appeals Chamber in Prosecutorv. Tadic. ${ }^{8}$ We find that the ICJ's approach in Bosnia v. Serbia was a sensible one, and that the ICJ's concern not to disrupt the consistency of jurisprudence within the ICTY, and within its own court, should be taken into account by those who are interested in the project of generating principled guidelines for consistency between international bodies.

With respect to the issue of fact finding, we first show how the ICJ drew inferences not only from the findings of guilt made by the ICTY, but also - problematically - from the absence of certain ICTY convictions, and even charges, in order to find that genocide had not occurred in Bosnia and Herzegovina in any region other than in Srebrenica. ${ }^{9}$ We then look at how the ICJ addressed the factual questions relating to whether Serbia could be held responsible for the Srebrenica genocide. We note that the failure of the ICJ to request unredacted versions of documents that Bosnia and Herzegovina believed would show that the genocide at Srebrenica could be attributed to the Serbian state, along with the ICJ's refusal to draw a negative inference from Serbia's failure to produce those documents, may turn out to be the this case's most troublesome legacy. ${ }^{\text {Io }}$

\section{THE LEGAL STANDARD FOR THE ATTRIBUTION OF STATE RESPONSIBILITY}

The past decade has produced an ongoing debate among legal scholars about the extent of disjunct between the jurisprudence of the ICJ and ICTY on the question of the appropriate legal standard for imputing the actions of an individual, or group of individuals, to a state. ${ }^{\text {II }}$ So far as the issue of state responsibility falls within the purview of international law, over which the ICJ has general jurisdiction, it is presumed to be more competent in this area than the ICTY, which has jurisdiction over issues of individual criminal responsibility. Indeed, in its decision in Nicaragua the ICJ established a test for the attribution of individual actions to a state almost a decade before the ICTY came into existence. ${ }^{12}$

\section{I. The ICJ's Nicaragua standard for attributing state responsibility}

In Nicaragua the ICJ needed to determine whether the acts of a group of non-state actors, the Contras, in Nicaragua, could be attributed to the United States. Under Nicaragua the Court determined that the actions of actors who are not organs of the state under the internal laws of the state can still be considered de facto organs of the state if their relationship is 'one of dependence on the one side and control on the

8. Prosecutor v. Tadić, Judgement, Case No. IT-94-I-A, App.Ch., I5 July I999 (hereinafter Tadić Appeal), para. I45.

9. Infra section 3.I.I.-3.I.2.

10. Infra section 3.2.I.

I I. See, e.g., M. Sassòli and G. Olson, 'International Decision: Prosecutor v. Tadić', (2000) 94 AJIL 57 I, at 575; M. A. Drumbl, 'Looking Up, Down and Across: The ICTY's Place in the International Legal Order', (2003) 37 New England Law Review I037, at I050-5I. D. Jinks, 'State Responsibility for Acts of Private Armed Groups', (2003) 4 Chicago Journal of International Law 83, at 89; M. Sassòli, 'State Responsibility for Violations of International Humanitarian Law', 2002 (June) 84 International Review of the Red Cross 40I, at 407-8.

I2. Nicaragua, supra note 6, at paras. IO9-IIO, I I5. 
other'. ${ }^{13}$ When a relationship of such 'complete dependence' is found, all the acts of those formally 'non-state' actors can be imputed to the state. However, even when this standard of 'complete dependence' is not met, the conduct of individuals may still be attributable to the state if the latter had effective control over the specific operations in the course of which such conduct took place. ${ }^{\text {I4 }}$

\subsection{The ICTY's use of Nicaragua to determine the nature of an armed conflict}

In 1997 the ICTY Trial Chamber introduced the Nicaragua decision into its jurisprudence in order to answer the question of whether or not the conflict in Bosnia and Herzegovina was an internal or an international armed conflict. ${ }^{15}$ This question was relevant to the work of the ICTY because under international humanitarian law (IHL) individuals can only be charged with 'grave breaches' crimes of the Geneva Conventions (as set out in Article 2 of the Statute of the ICTY) committed during an international, but not internal, armed conflict, ${ }^{16}$ and only if their victims are 'protected persons' under Article IV of the Geneva Conventions. ${ }^{17}$

When an armed conflict involves two sovereign states, the conflict is obviously international. However, when the conflict involves a state and one or more nonstate actors, even though operating across international borders, as in the case of the former Yugoslavia, it becomes necessary to impute the actions of the non-state actors to another sovereign state in order to determine that the conflict is international. Without such an attribution the conflict is viewed as internal and so the 'grave breaches' regime of the Geneva Conventions does not apply. ${ }^{18}$

Prior to the break-up of the former Yugoslavia, what was then the Socialist Federal Republic of Yugoslavia (SFRY) maintained a national Yugoslav People's Army (JNA). During the break-up of the SFRY the political leadership in the Serb-controlled region of Bosnia and Herzegovina formed its own entity called the Serb Republic of Bosnia and Herzegovina (subsequently Republika Srpska). On I 2 May I 992 the Army of Republika Srpska (VRS) was formed. Pursuant to a UN Security Council resolution, ${ }^{\text {I9 }}$ the FRY formally withdrew JNA forces from Bosnia and Herzegovina on I 9 May I 992. However, not only were troops of Bosnian Serb origin from throughout the JNA transferred into the VRS, but the FRY maintained control over the VRS. ${ }^{20}$ The extent of that control became a key issue for the ICTY cases dealing with atrocities

I3. Ibid., para. Io9.

I4. Ibid., para. II5.

I5. Although as the former ICTY president Theodore Meron points out, the Nicaragua case was first 'discovered' by the ICTY in a review of the Indictment in Prosecutor v. Rajic, Review of the Indictment Pursuant to Rule 6I, Case No. IT-95-I2-R6r, T. Ch., I3 September 1996. See T. Meron, 'Classification of Armed Conflict in the Former Yugoslavia: Nicaragua's Fallout,'( 1998 ) 92 AJIL 236, at 240.

I6. Prosecutor v. Tadić, Defence Motion for Appeal on Jurisdiction, Case No. IT-94-I-AR72, A. Ch., 2 October I995, para. 84.

I7. Tadić Appeal, supra note 8 , at paras. $80-82$.

I8. For a compelling argument in favour of the extension of the 'grave breaches' regime to non-international armed conflicts, see T. Meron, 'International Criminalization of Internal Atrocities,' (I995) 89 AJIL 554. See also Prosecutor $v$. Tadić, Separate Opinion of Judge Abi-Saab on the Defence Motion for Interlocutory Appeal on Jurisdiction, Case IT-94-I-AR72, 5-6, 2 October I995, para 5.

I9. SC Res. 752, UN Doc. S/RES/752 (I992), para. 4.

20. Prosecutorv. Tadic, Opinion and Judgement, CaseNo.IT-94-I-T, T.Ch.II, 7 May I997, paras. I I 3-I I 8 (hereinafter Tadić trial judgment). 
committed in Bosnia and Herzegovina after the formal withdrawal date. ${ }^{21}$ If the control that the FRY had over the VRS in Bosnia and Herzegovina was sufficient to impute the acts of the VRS to the FRY, then the conflict in Bosnia and Herzegovina could be considered 'international' for the purposes of IHL and, accordingly, those brought before the Tribunal could be charged with crimes against protected persons under the 'grave breaches' regime of the Geneva Conventions. ${ }^{22}$

\subsection{The ICTY trial chamber's use of Nicaragua in Tadić}

Duško Tadić was a café owner and karate expert who had access to the detention camps in Prijedor, in Bosnia and Herzegovina, and was brought before the ICTY on charges of war crimes and crimes against humanity that allegedly occurred in the camps in I992. In Prosecutor v. Tadic, the trial chamber had to decide whether, after the formal withdrawal of the JNA from Bosnia and Herzegovina, the FRY nevertheless maintained sufficient control over the VRS that the VRS was essentially a de facto organ of the FRY. ${ }^{23}$ If so, this relationship would 'internationalize' the conflict for the purposes of IHL, with the result that Tadic could be charged with 'grave breaches' crimes against those detained within the camps.

In making its analysis, the trial chamber invoked Nicaragua. Although it acknowledged that the key issue before the ICJ in Nicaragua was whether the accused state could be held responsible for violations of IHL, it went on to justify its invocation of Nicaragua on the grounds that the ICJ also had to decide which part of IHL to apply to the conflict. ${ }^{24}$ As applied to the case before it, the trial chamber understood that for the 'grave breaches' regime to come into force, Nicaragua required the prosecution to prove that after the formal withdrawal of troops on I9 May I992, the FRY nevertheless maintained 'effective control' over the specific operations of the newly formed VRS. ${ }^{25}$

In applying the stringent 'effective control' test to the facts of the case, the trial chamber concluded that the standard was not met and that therefore the 'grave breaches' regime of the Geneva Conventions did not apply. ${ }^{26}$

In a strong dissenting opinion, Presiding Judge McDonald argued that the majority had misinterpreted Nicaragua, and that the 'effective control' test is a subsidiary test to be applied only when no 'agency' relationship has been found between the state and the non-state actors in question. ${ }^{27}$ What Judge McDonald referred to as the 'agency test' the court in Nicaragua had explained as a relationship that is 'one

\footnotetext{
2I. The extent of control that the FRY maintained over the VRS also became a critical issue for the ICJ in Bosnia v. Serbia as it tried to determine whether the acts of the VRS at Srebrenica could be attributed to the Serbian state. See infra section 3.2.

22. See Tadić trial judgment, supra note 20 , at para. 560 .

23. Tadić trial judgment, supra note 20 , para. 587 .

24. Ibid., at para. 585. As subsequently observed by commentators, the part of the Nicaragua judgment that determined that the rules of international armed conflict could be applied to US-Nicaragua relations was not dependent on the outcome of any attribution test. See, e.g., Meron, supra note I5, at 24I.

25. Tadić trial judgment, supra note 20 , at paras. 588,595 .

26. Ibid., at para. 605 .

27. Ibid., Separate and Dissenting Opinion of Judge McDonald Regarding the Applicability of Article 2 of the Statute, para. 22 (hereinafter Tadić McDonald dissent).
} 
of dependence on the one side and control on the other'. ${ }^{28}$ In other words, if the non-state actor or group does not have such a relationship of complete dependency on the state to be considered its agent, only then should the question be asked as to whether the state exercised such effective control over specific operations of those groups that it might nevertheless be appropriate to hold the state accountable for violations committed in those specific operations. More fundamentally, Judge McDonald disagreed with the trial chamber majority that the Nicaragua case was even relevant in determining the nature of the conflict for the purposes of finding individual criminal responsibility: "The inapplicability of the Nicaragua standard of effective control is patent; it was neither designed for these factual circumstances nor is it an appropriate consideration.'29

\subsection{The ICTY Appeals Chamber's rejection of the ICJ's Nicaragua standard}

In I 999 the ICTY Appeals Chamber entered the fray, creating an explicit conflict with Nicaragua. ${ }^{30}$ The Appeals Chamber agreed with the trial chamber that Nicaragua was relevant to determining the nature of the armed conflict. Rejecting Judge McDonald's dissenting argument that Nicaragua should not be used to assess the nature of the conflict, the Appeals Chamber explained,

What is at issue is ... the conditions on which under international law an individual may be held to act as a de facto organ of a State. Logically these conditions must be the same both in the case: (i) where the court's task is to ascertain whether an act performed by an individual may be attributed to a State, thereby generating the international responsibility of that State; and (ii) where the court must instead determine whether individuals are acting as de facto State officials, thereby rendering the conflict international and thus setting the necessary precondition for the 'grave breaches' regime to apply. ${ }^{3 \text { I }}$

The Appeals Chamber also disagreed with Judge McDonald's assertion that the 'effective control' test in Nicaragua was a subsidiary test to what she had termed the 'agency' test. ${ }^{32}$ However, it also disagreed with the trial chamber majority's acceptance of Nicaragua's 'effective control' test, and in an unexpected move it set itself up in direct conflict with the ICJ, stating that 'the Appeals Chamber, with respect, does not hold the Nicaragua [effective control] test to be persuasive'. ${ }^{33}$ Its justification for this attack on the jurisprudence of the ICJ was that the 'effective control' test did not comport either with the logic of the law of state responsibility, ${ }^{34}$ or with judicial or state practice. ${ }^{35}$

\footnotetext{
28. Nicaragua, supra note 6 , at para. Io9.

29. Tadic McDonald dissent, supra note 27 , at para. 32.

30. Tadí́ Appeal, supra note 8, at para.II5.

3I. Ibid., at para. I04 (emphasis omitted).

32. Ibid., at para. II2.

33. Ibid., at para. II5.

34. Ibid., at paras. I $16-123$.

35. Ibid., at paras. I24-I36. The Appeals Chamber's interpretation of some of the cases that it claims represent 'state practice' on the issue of state responsibility has been criticized. See M. Milanović, 'State Responsibility for Genocide,' (2006) I7 EJIL 553 at 586 (arguing that the cases relied on by the Appeals Chamber represent issues of attribution for the purposes of outsourcing (Kenneth P. Yeager v. Islamic Republic of Iran, I 7 Iran-US Claims Tribunal Reports ( $\mathrm{I987}$ )) and establishing territorial jurisdiction as a prerequisite to the obligations of
} 
The Appeals Chamber held that international law proposes different tests of state responsibility which are applied on the basis of the type of actor whose behaviour is being assigned for attribution. The first test applies when the actor is an individual or part of a group that is not militarily organized; in this case evidence of specific instructions by the state must be proven, or the state must ratify the conduct. ${ }^{36}$ The second test applies when the actor is part of an organized paramilitary structure; in this case a lesser standard of 'overall control', which the Chamber explains must 'comprise more than the mere provision of financial assistance or military equipment or training', must be shown. ${ }^{37}$ The Chamber also makes a fairly cursory reference to a third test that seems akin to a notion of apparent authority, whereby the actions of individuals can be attributed to the state when those actions approximate the behaviour of a person who is part of an organ of the state..$^{88}$

The handling of Nicaragua in the Tadićappeal has been criticized, not only for the substance of what the Appeals Chamber said about the 'effective control' test, ${ }^{39}$ but also for the fact that the Appeals Chamber even addressed the Nicaragua test in the first place..$^{4^{\circ}}$ It is not too difficult to see the intuition behind the ICTY's general inclination to look for an attribution test in trying to determine whether an external state exercises so much control over the actions of a group of non-state actors that the conflict is substantively an international one..$^{41}$ Nevertheless, the Appeals Chamber violated the basic principle of judicial economy by offering a wholesale criticism of the validity of the Nicaragua attribution test for the purposes of state responsibility, when the only issue it needed to decide in the case before it was whether the alleged acts with which Tadić was charged took place within an international or an internal armed conflict. It was therefore not surprising that when presented with a case that required the application of this test of attribution, the ICJ would take the opportunity to explicate its position on Nicaragua in the context of comments made by the ICTY in the Tadic appeal.

\subsection{The ICJ's response to the ICTY's attack on Nicaragua}

Given the aggressive attack that the ICTY Appeals Chamber had launched on the ICJ's Nicaragua attribution test, the ICJ was fairly measured in its response to the issue in Serbia v. Bosnia. Avoiding a tit-for-tat approach, the Court did not try to argue

human rights treaties (Loizidou v. Turkey (Merits), ECHR, Judgment of I 8 December I996) (40/1993/435/5I4), rather than the attribution of individual acts to the state).

36. Tadic Appeal, supra note 8 , at para. I37.

37. Ibid.

38. Ibid., at para. I4I.

39. See Milanović, supra note 35 , at $58 \mathrm{I}$.

40. See, e.g., M. C. Bassiouni, "The Normative Framework of International Humanitarian Law: Overlaps, Gaps and Ambiguities,' (I998) 8 Transnational Law and Contemporary Problems I99, at 226-7; Sassòli and Olson, supra note II, at 578; International Law Commission, 'Report on the Work of its Fifty-Third Commission,' (200I) A/56/Io at I06 (Commentary to Article 8 suggesting that the ICTY's competence is not on the issue of the appropriate standard for state responsibility).

4I. There is, however, a persuasive argument to be made that there was no need for a specific test on this issue since the guidance provided by IHL and the principles of international law more generally are sufficient for the task. See Meron, supra note I5, at 24I. 
that the ICTY had been incorrect with respect to the issue that had been before it namely how to determine the nature of the conflict. Specifically, the ICJ noted that

Insofar as the [ICTY's] 'overall control' test is employed to determine whether or not an armed conflict is international ... it may well be that the test is applicable and suitable; the Court does not however think it appropriate to take a position on the point in the present case. ${ }^{42}$

This was wise, since just as state responsibility is not within the ICTY's area of special expertise, neither is the characterization of the nature of a conflict for the purpose of applying IHL to individual actors within the ICJ's area of specialty. However in respect to the ICTY's further claim that the 'overall control' test should also be applied to questions of state responsibility for the acts of non-state organs, the Court was outright in its rejection of the Appeals Chamber's approach. ${ }^{43}$ Directly rebutting the Tadic Appeal Chamber's argument that logic required a single test to answer both the question of state responsibility and the question of the nature of an armed conflict, the Court stated,

[T] he degree and nature of a State's involvement in an armed conflict on another State's territory which is required for the conflict to be characterized as international, can very well, and without logical inconsistency, differ from the degree and nature of involvement required to give rise to that State's responsibility for a specific act committed in the course of the conflict. ${ }^{44}$

Accordingly, the final outcome of the interplay between the ICJ and ICTY on this question of attribution suggests that the ICJ will continue to use its Nicaragua test in assessing questions of state responsibility that come before it, and that the ICTY will continue to use its 'overall control' test in characterizing whether a conflict is internal or international for the purposes of applying the 'grave breaches' regime of IHL.

The ICJ's language of deference towards the ICTY with regard to the issues that come before that Tribunal give the appearance of a court that is being guided by principles of judicial restraint: the ICJ commented as much as was necessary for it to adjudicate the case before it, while reserving judgment on the appropriateness of the ICTY's approach to the questions it faces. However, the Court's approach might also be understood as having been driven by purely pragmatic concerns. One might observe the likely futility had the ICJ attempted to fight the ICTY's judgment on the issue of how to assess the nature of the conflict, given that since the Tadic appeal the ICTY has developed a solid body of jurisprudence that is grounded in the 'overall control' test for determining the nature of the conflict, ${ }^{45}$ and to which the Pre-trial Chamber of the ICC has already referred approvingly. ${ }^{46}$ To the extent that

\footnotetext{
42. Bosnia v. Serbia, supra note I, at para. 404 .

43. Ibid.

44. Ibid., at para 405. Cf. Tadić Appeal, supra note 8, at para. I04.

45. See, e.g., Prosecutor v. Aleksouski, Appeals Judgement, Case No. IT-95-I4/I-A, 24 March 2000, paras. I3I-I34; Prosecutor v. Celebici Appeals Judgement, Case No. IT-96-2I-A, 20 February 200I, para. 26; Prosecutor v. Kordic and Cerkez, Appeals Judgement, Case No. IT-95-I4/2-A, I 7 December 2004, paras. 299-3I3.

46. See 'Décision sur la confirmation des charges', Pre-trial Chamber of the International Criminal Court, ICCOI/O4-OI/O6-803, 29 January 2007, paras. 2 IO-2II.
} 
this more pragmatic view has any credence, it may just be the by-product of a current legal order in which there have not yet been any formal or enforced guidelines to govern the interrelationship between the ICJ and the ICTY. However, this possibility notwithstanding, the lesson from Bosnia v. Serbia may well be that any attempt to guide different international adjudicative bodies towards a principled system in order to avoid the potential for fragmented jurisprudence between the international bodies will need to be flexible enough to accommodate the concerns for consistency within each of the international bodies.

\section{FACT FINDING}

There were two heavily fact-dependent questions that the Court had to resolve in the case before it. Did genocide take place in Bosnia and Herzegovina? And if so, could Serbia be held responsible?

As a threshold issue, the Court first addressed Serbia's question of whether, as a matter of law, it would be possible to find a state responsible for genocide in the absence of an individual, over whom the state had control, having first been held criminally liable for genocide by a duly constituted court. ${ }^{47}$ Answering in the affirmative, the Court pointed out that the Statute of the ICJ authorized it to undertake the task of deciding if genocide had been committed by a state, and that the Genocide Convention gave it jurisdiction over this task. ${ }^{48}$ Furthermore, the Court observed that any alternative answer would lead to an outcome whereby there might be no legal recourse available to victims of genocide in a situation in which, due to political constraints, the individual perpetrators had not been held accountable: The Court accordingly concludes that state responsibility can arise under the Convention for genocide or complicity, without an individual being convicted of the crime or an associated one. ${ }^{49}$ In our view, this is an entirely correct statement. However, as the following elucidates, the Court's fact-finding approach in this test case raises doubts as to whether, in practice, a state will ever be held responsible for genocide outside the parameters of the prior convictions of individual perpetrators.

\section{I. Was genocide committed in Bosnia and Herzegovina?}

To answer this question the Court needed evidence of both the actus reus of genocide (the acts set out in paragraphs (a) to (e) of Article II of the Genocide Convention, such as killing, causing serious bodily or mental harm, and forcibly transferring children) and the dolus specialis (that those acts were 'committed with intent to destroy, in whole or in part, a national, ethnical, racial or religious group, as such' - as set out in the chapeau of Article II of the Genocide Convention). In terms of the question of whether genocide had been committed in Bosnia and Herzegovina, the ICJ was highly deferential to the findings of the ICTY, which has competence to decide both

\footnotetext{
47. Bosnia u. Serbia, supra note I, at para. I80.

48. Ibid., at para. I8I.

49. Ibid., at para. 182 .
} 
these issues with respect to whether individual alleged perpetrators can be held liable for genocide.

The Court was careful to lay out the different weights it proposed to give to findings presented from different stages of the ICTY's process, from indictment through to appeal, recognizing that because no definitive rulings are made before the conclusion of a trial, it would not be appropriate for the Court to give weight to evidence elicited from pre-trial stages because the standard of proof at those stages is lower than the standard the Court was using in Bosnia v. Serbia. ${ }^{50}$ However, this decision notwithstanding, the Court made a point of noting that while the inclusion of charges in an indictment could not be accorded evidentiary weight, the Prosecutor's decision to 'not include or to exclude' a genocide charge from an indictment might be 'significant'. ${ }^{\mathrm{I}}$ The Court did not, however, offer any explanation for why this would be so.

Having laid out this framework, the Court then proceeded to consider the factual evidence presented to it under the categories established by Article II of the Genocide Convention. The subsequent I 22 paragraphs of the judgment are largely devoted to laying out the evidence presented by the parties, and in particular summarizing the findings of the judgments of the ICTY. In the process, the Court found there to be persuasive and conclusive evidence that the material elements (actus reus) of genocide were committed with respect to Genocide Convention Article II(a) ${ }^{52}$ (killing members of a protected group), Article II(b) ${ }^{53}$ (causing serious bodily or mental harm to members of the protected group), and Article II(c) ${ }^{54}$ (deliberately inflicting on the group conditions of life intended to bring about the destruction of the group in whole or in part), but not with respect to Articles II(d) $)^{55}$ or II(e)..$^{6}$

With regard to dolus specialis, however, the Court found that in all instances, except for the massacres at Srebrenica, the specific intent element required to reach a finding of genocide was not established. ${ }^{57}$ The Court's primary basis for finding that the specific-intent element of genocide was established with respect to the massacres at Srebrenica was the ICTY trial and appellate judgments in Prosecutorv. Krstic. ${ }^{8}$ In the Krstic judgments the ICTY Trial and Appeals Chambers found that genocide had been committed in Srebrenica, and the Court concluded that it had 'no

50. Ibid., at para. 2I9. On the issue of the standard of proof, Bosnia argued that because this was a civil case, a preponderance of the evidence standard should be used. Serbia argued that given the exceptional gravity of the accusation, the standard should be beyond a reasonable doubt. Using its language from Corfu Channel (United Kingdom v. Albania), [I949] ICJ Rep. 4, the Court essentially favoured Serbia's view, holding that a 'fully conclusive' standard of proof was appropriate for a crime as serious as genocide, Bosnia u. Serbia, supra note I, at para. 209. Then, the Court stated that 'the same standard applies to the proof of attribution for such acts' without providing any additional justification for why this should be so. Ibid.

5I. Bosnia v. Serbia, supra note I, at para. 2 I7.

52. Ibid., at paras. $276,297$.

53. Ibid., at para. 3 I 9 .

54. Ibid., at paras. 334, 354.

55. Ibid., at para. 361.

56. Ibid., at para. 367.

57. Ibid., at paras. 277, 319, 334, 354 .

58. Prosecutor v. Krstic, Judgement, Case No. IT-98-33, T.Ch. I, 2 August 200I; Prosecutor v. Krstic, Judgement, Case No. IT-98-33-A. A.Ch., I9 April 2004. 
reason to disagree' with the ICTY's findings on this issue..$^{59}$ Accepting its reasoned explanation for why it would give evidentiary significance to the judgments of the ICTY, ${ }^{60}$ this part of the Court's judgment is unobjectionable. However the Court's basis for finding that specific intent had not been established in other situations in which the material element of genocide had been established was much less convincing.

\section{I.I. Drawing inferences from the absence of ICTY convictions}

With respect to the massive killings that the Court found had been committed in areas of Bosnia and Herzegovina other than Srebrenica, the Court's justification for finding that the specific-intent element had not been established was on the grounds that it 'carefully examined the criminal proceedings of the ICTY and the findings of its chambers... and observes that none of those convicted were found to have acted with specific intent (dolus specialis). ${ }^{6 \mathrm{I}}$ The Court applies the same justification to its finding that the specific-intent element was not established with respect to the material acts it found had been committed against the protected group under Article II(c) of the Genocide Convention in a number of detention camps across Bosnia and Herzegovina. In explaining its inability to find specific intent, the Court states that 'in none of the ICTY cases concerning the camps cited above has the Tribunal found that the accused acted with such specific intent. ${ }^{62}$

The problem with the Court's reasoning is that the question before it at that stage was whether genocide had occurred in Bosnia and Herzegovina, not whether genocide was committed by the relative handful of individuals who have to date been prosecuted by the ICTY. The ICTY does not have the resources or the mandate to investigate every possible charge of genocide arising out of the horrific crimes committed in Bosnia and Herzegovina since I 99I. Furthermore, the ICTY was never judging whether genocide occurred at a given location or time, but rather whether an individual before it was responsible for a particular act of genocide or not. It is therefore inappropriate to draw inferences about whether genocide did or did not take place based on what the ICTY chambers have not found to be substantiated beyond a reasonable doubt, in respect of any given individual.

Further problematic is that the Court appears to give weight to the absence of a conviction for genocide occurring in a place other than Srebrenica in instances in which the accused died before or during proceedings (Milošević, Talić, Kovačević and Drljača), ${ }^{63}$ or in which a case with an indictment that includes a genocide charge has not yet gone to trial (Karadžić and Mladić) ${ }^{6}{ }^{6}$ In doing so, the Court implies that had Milošević, for example, survived trial and been convicted of the crimes for which he was indicted, or had Karadžić and Mladić been arrested and brought to trial, then

59. Bosnia v. Serbia, supra note I, at para. 296.

60. See ibid., at para. 2 I4 (explaining that the fact-finding of the ICTY uses "evidence obtained by examination of persons directly involved, tested by cross examination, the credibility of which has not been challenged subsequently') (internal quotations omitted).

6I. Ibid., at para. 277.

62. Ibid., at para. 354 .

63. Ibid., at paras. $374(\mathrm{e})(\mathrm{f})$.

64. Ibid., at para. $374(\mathrm{~g})$. 
the Court might have reached a different outcome in the Bosnia v. Serbia case before it. This line of reasoning is likely to be particularly frustrating for Bosnian victims when in a different part of the judgment the Court holds Serbia responsible for failing to arrest Mladić. ${ }^{65}$ While the availability of evidence will always have an effect on the outcome of judicial proceedings, the availability or not of judgments before one tribunal should not be determinative of the outcome of proceedings before another independent body, especially if other sources of evidence or avenues of inquiry remain open, and least of all on a matter of this gravity and importance.

The Court's deference to the ICTY's findings was sensible to the extent that it would have been unnecessarily duplicative for the ICJ itself to determine those facts which had already been authoritatively established by the ICTY, and especially when there is general acceptance regarding the rigour of the ICTY's own fact-finding process. ${ }^{66}$ However, the inferences it appeared to draw from the absence of findings in circumstances where that absence may not be probative on the issue of whether or not genocide had actually taken place (as opposed to the distinct issue of whether the ICTY had proved that a particular accused before it had committed genocide) show the dangers of an uncritical approach to the incorporation of actions and findings of one adjudicative body by another.

\subsubsection{Drawing inferences from the absence of ICTY charges}

The Court reaches its conclusion that specific intent was lacking in all situations other than Srebrenica not only by drawing negative inferences from the absence of ICTY genocide convictions; it also gives weight to the absence of ICTY genocide charges. In one of the most questionable portions of the judgment the Court applies this belief in the significance of what is not in an indictment to refute Bosnia and Herzegovina's proposition that the pattern of atrocities, committed across many regions, demonstrated specific intent. In coming to the conclusion that specific intent could not be inferred from the pattern of atrocities, the Court not only relies on the ICTY findings, but also on 'actions of the Prosecutor [of the ICTY], including decisions not to charge genocide offences in possibly relevant indictments, and to enter into plea agreements . . . by which the genocide-related charges were withdrawn'. ${ }^{67}$

Giving evidentiary weight to the Prosecutor's decision not to include a genocide charge in any given indictment, or to negotiate a plea agreement that involves withdrawing a genocide charge, is troublesome. First, the Prosecutor's decision not to charge genocide in an indictment may have nothing at all to do with the absence of evidence that genocide was committed in any particular situation. The evidence might indeed be conclusive as to the actus reus but wanting with regard to the criminal liability of the particular individual accused person or persons before the Tribunal. Second, crucial evidence may have been obtained from a state intelligence source under the provisions of Rule $70 \mathrm{~B}$ of the ICTY Rules of Procedure and Evidence. Reference to such evidence in an indictment would thus be precluded. And, with

65. Ibid., at paras. $448-50$.

66. See supra note 60 .

67. Bosnia v. Serbia, supra note I, at para. 374 (emphasis added). 
regard to a plea agreement, the acceptance by the Prosecutor of a confession of guilt to a less serious crime than genocide might well be driven by the advantages of avoiding a lengthy trial or the unavailability of essential evidence. There might, indeed, be other weaknesses in the prosecution case that are unrelated to whether or not genocide was actually committed.

\subsection{Can the genocide at Srebrenica be attributed to Serbia?}

Having found that, with respect to the first question, the massacre at Srebrenica, led by members of the VRS, was the only instance in which genocide took place in Bosnia and Herzegovina, ${ }^{68}$ the Court then turned to the second question of whether the Serbian state could be held responsible for that case of genocide. Because the genocide at Srebrenica took place in July i 995, after the formal withdrawal of the JNA troops from Bosnia and Herzegovina, ${ }^{69}$ the critical issue before the Court was whether the acts of the VRS at Srebrenica could be attributed to the Serbian state. In this respect, the extent of control that the FRY had over the VRS became a critical issue.

The question of whether the Serbian state can be held responsible for genocide at Srebrenica is not an issue that the ICTY has the jurisdiction to answer, because its Statute confines it to deciding issues of individual criminal responsibility. ${ }^{70}$ Thus while evidence obtained through the ICTY could go some way towards answering the question of state responsibility, the Court was unable to rely directly on the conclusions that the ICTY had drawn from the facts before it with regard to this question. Instead, the Court applied its two-part Nicaragua standard ${ }^{71}$ and the ILC Articles 4 and 8 on State Responsibility ${ }^{72}$ to evidence presented by the parties from a range of sources. ${ }^{73}$

\subsection{Access to unredacted documents}

The Court stated at the outset of its analysis that it is the applicant - in this case Bosnia and Herzegovina - who has the burden of proof in establishing its case and proving the facts it asserts. ${ }^{74}$ Bosnia and Herzegovina accepted this as a general proposition, but put forth the argument that the burden should be reversed on the specific question of whether acts of genocide could be attributed to Serbia. Its rationale for this request was that Serbia had refused to provide unredacted versions

\footnotetext{
68. Ibid., at paras. 297,376 .

69. See text accompanying supra note $2 \mathrm{I}$.

70. Statute of the International Criminal Tribunal for the former Yugoslavia, UN Doc. S/RES/827 (I993), Article I.

7I. See supra section 2.I.

72. See J. Crawford, The International Law Commission's Articles on State Responsibility (2002), 94 (under Article 4 of the ILC Articles on State Responsibility, actions of people or entities that have the status of state organs under the internal law of the state, will be attributed to the state itself.); ibid., at i Io (under Article 8 of the ILC Articles on State Responsibility, the acts of certain non-state actors can be attributed to the state when they are 'in fact acting on the instructions of, or under the control of, that State in carrying out the conduct'.) In Bosnia v. Serbia the ICJ uses the language of Article 8 and of the 'effective control' test under Nicaragua interchangeably. See Bosnia v. Serbia, supra note I, para. 400 .

73. Ibid., paras $385-4$ I 2 .

74. Ibid., para. 204 .
} 
of documents from the FRY's Supreme Defence Council(FRY Council) meetings that Bosnia and Herzegovina believed would be probative on the issue of state control over the massacre at Srebrenica. ${ }^{75}$

The FRY Council consisted of the highest-ranking political and military officers of the FRY and was the constitutionally highest authority over the military during the events in question. ${ }^{76}$ In oral argument, counsel for Bosnia and Herzegovina argued that the unredacted versions of the minutes of the FRY Council meetings could be expected to show orders given by the FRY to armed forces in Bosnia and Herzegovina and payment by the FRY to officers in the VRS ${ }^{77}$ - both of which would have been central to proving that the FRY exercised effective control over the actions of the VRS at Srebrenica.

In what has since become one of the most controversial parts of the Court's judgment, ${ }^{78}$ the Court not only refused to request unredacted versions of the documents from Serbia (as the Court acknowledged it has the authority to do through its proprio motu powers under Article 49 of the Statute of the ICI and Article 62 of the Rules of the Court); ${ }^{79}$ it also refused to draw any inferences on account of Serbia's failure to provide unredacted versions of those documents. ${ }^{80}$

In attempting to justify its decision, the Court noted that Bosnia and Herzegovina had 'extensive documentation and other evidence available to it, especially from the readily accessible ICTY records. ${ }^{{ }^{8}}{ }^{\mathrm{I}}$ This is hardly persuasive, given that Bosnia and Herzegovina's reason for requesting unredacted versions of these documents was that it believed these documents would provide evidence on the issue of attribution that was not clear from the documentation it already had available to it. The unredacted documents were not available to Bosnia and Herzegovina from the ICTY because of a confidentiality order imposed by the Tribunal at Serbia's request.

\subsubsection{Was the VRS a de facto organ of the FRY?}

Having refused Bosnia and Herzegovina's request to demand unredacted versions of the FRY Council documents from Serbia, the Court assessed the question of attribution on the basis of the redacted versions of the FRY Council documents and other evidence presented by the parties.

With regard to whether the actors involved in the genocide at Srebrenica were de jure organs of the Serbian state, the Court looked to facts elicited through the ICTY and to intercepted documents, presented by Bosnia and Herzegovina, referring to the paramilitary group, the Scorpions, as a 'unit of the Minister of the Interior of Serbia' and as 'the MUP of Serbia'. ${ }^{82}$ In what could only be called a cursory consideration of the evidence on this point, the Court concluded that there was not sufficient

75. Ibid

76. M. Milanović, 'State Responsibility for Genocide: A Follow-Up', (2007) I8 (4) EJIL 677, at n. 34.

77. Bosnia v. Serbia, supra note I, CR 2006/30, I8 April 2006, para. I9 (Beisen).

78. See, e.g., R. Wedgwood, 'Slobodan Milošević's Last Waltz', International Herald Tribune, I 2 March 2007; M. Simons, 'Genocide Court Ruled for Serbia Without Seeing Full War Archive', New York Times, 9 April 2007.

79. Bosnia v. Serbia, supra note I, at para. 44 .

80. Ibid., at para. 206.

8I. Ibid.

82. Ibid., at para. 389 . 
evidence that either the VRS or Republika Srpska satisfied the standard of being completely dependent on the FRY, ${ }^{83}$ or that the Scorpions were acting in complete dependence on the FRY. ${ }^{84}$

In another telling example of the Court's dependence on the ICTY for fact finding, the Court noted that the Stanišic and Simatović case pending before the ICTY might provide evidence of a relationship of complete dependence between the Scorpions and the Serbian state. However, it went on to say that 'the Court cannot draw further conclusions as this case remains at the indictment stage. ${ }^{85}$ Thus the question lingers as to whether a more expeditious trial in the ICTY's Stanišić and Simatovićcase could have provided evidence for the ICJ that the Scorpions were completely dependant on the FRY, thereby generating a potentially different outcome in the Bosnia v. Serbia case. Furthermore, if a relationship of complete dependence between the Scorpions and the FRY does come out subsequently in the Stanišic and Simatović case, then the finality of the ICJ's finding on this issue may be questioned.

\subsubsection{Did the FRY have effective control over the VRS?}

Having found that the test of complete dependence was not met, the Court moved to the next test of whether the FRY nevertheless had 'effective control' over specific operations carried out by the actors involved in the Srebrenica massacre. The Court referenced reports by the Secretary-General of the United Nations, ${ }^{86}$ the Netherlands Institute for War Documentation, ${ }^{87}$ and the US Central Intelligence Agency. ${ }^{88}$ Again, the Court concluded that the evidence was not sufficient to establish that Serbia had effective control over the acts constituting genocide at Srebrenica, observing that

The applicant has not proved that instructions were issued by Federal authorities, or by any other organ of the FRY, to commit such massacres, still less that any such instructions were given with the specific intent characterizing the crime of genocide, which would have to be present in order for the Respondent to be held responsible on this basis. $^{89}$

The Court denied that Serbia had effective control over the actors at Srebrenica because of the absence of evidence of instructions from the FRY to commit the massacre. However, it is exactly such instructions that Bosnia and Herzegovina claimed were likely to be found in the unredacted versions of the FRY Council documents.

\subsubsection{The ICJ's inadequate response to the issue of unredacted documents}

Given that the Court found insufficient evidence to attribute the genocide at Srebrenica to Serbia, the Court's failure to request unredacted versions of documents that

\footnotetext{
83. Ibid., at para. 394 .

84. Ibid., at para. 395. For an excellent critique of the ICJ's passivity with regards to seeking out publicly available information regarding the relationship between the Scorpions and the FRY, see Milanović, supra note 76 .

85. Bosnia v. Serbia, supra note I, para. 395.

86. Ibid., at para. 408.

87. Ibid., at para. 4IO.

88. Ibid., at para. 4I 2.

89. Ibid., at para. $4 \mathrm{I} 3$.
} 
may have been probative on the issue is likely to damage the legitimacy of the Court's judgment in the eyes of many. Of course, only Serbia, the judges of the ICTY trial chamber, and some members of the ICTY Office of the Prosecutor know how probative the unredacted versions of the Supreme Defence Council documents actually are. However, it is not an unreasonable assumption that Serbia's argument that it cannot provide unredacted versions on the grounds of its national security interests, some I 5 years after the period in question, is but a veil to keep hidden evidence of a more explicit link between the FRY and the acts taken by the VRS at Srebrenica. ${ }^{90}$ The unredacted documents may have also provided evidence of the specific-intent element that the ICJ failed to find regarding the commission of genocide in other areas of Bosnia and Herzegovina. ${ }^{91}$

What is particularly frustrating is that this is an issue that the Court could so easily have avoided. Not only did it have the authority to request the documents, but, if Serbia had refused its request, it also had the authority to draw a negative inference from Serbia's refusal. As Vice-President Al-Khasawneh points out in his dissent, the Court itself has previously explained that there is an inherent inequity in asking a victim state to provide evidence of the accused state's direct control when the accused state retains control over the proof that would establish such control. ${ }^{92}$ Accordingly, the Court in Corfu Channel (United Kingdom v. Albania) ${ }^{93}$ explained that the victim state 'should be allowed a more liberal recourse to inferences of fact and circumstantial evidence. ${ }^{4}$ However, the Court took neither of the options readily available to it.

Even if, in actuality, the unredacted versions of the documents would not have provided the explicit link between the FRY and genocide at Srebrenica that the Court needed to hold the Serbian state responsible, the perception of unfairness generated by the Court's refusal even to ask for the documents is a sad legacy to leave following I 4 years of litigation on this case. At its best, an international judicial process - like any form of adjudication that is perceived to be legitimate - has the potential to lay contested issues to rest, thereby allowing those affected to move into a phase of healing and a more stable form of coexistence, if not complete reconciliation. By refusing, without any plausible justification, to request unredacted versions of the documents, the Court undermined its potential to play this much needed role in the region.

90. Lawyers who have seen the files have spoken on condition of anonymity, saying that the documents showed 'how Belgrade financed and supplied the war in Bosnia, and how the Bosnian Serb army, though officially separate after 1992, remained virtually an extension of the Yugoslav Army ... [and that]... Serbian forces, including secret police, played a role in the takeover of Srebrenica and in the preparation of the massacre there'. Simons, supra note 79 .

9I. In the course of the Miloševic trial, the trial chamber of the ICTY concluded that 'there is sufficient evidence that genocide was committed in Brcko, Prijedor, Sanski Most, Srebrenica, Bijeljina, Kljuc and Bosanski Novi'. Prosecutor v. Slobodan Miloševic, Decision on Motion for Judgement of Acquittal, Case No. IT-02-54-T, I6 June 2004, para. 289. This statement was made in the Decision on Motion for Judgement of Acquittal of Milošević in June 2004, after the trial chamber had access to the unredacted versions of the FRY Council documents, but of course does not carry the evidentiary weight of a final judgment.

92. Bosnia v. Serbia, supra note I, Dissenting Opinion of Vice-President Al-Khasawneh, para. 35.

93. Corfu Channel, supra note 50, Merits, Judgment of 9 April I949.

94. Ibid., at 18 . 


\section{Conclusion}

In Bosnia v. Serbia, the UN's principal adjudicative body held that, as a matter of law, it can find a state responsible for the commission of genocide. As the first case to be adjudicated by the ICJ on this question in the almost sixty years since the Genocide Convention was adopted, this alone makes for a historic moment in international law. However, the ICJ's approach to dealing with legal and factual issues that overlapped with the work of the ICTY will also become a focal point for those interested in the development of international law in the coming years.

The ICJ's approach in Bosnia v. Serbia to the challenge the ICTY raised against the Nicaragua standard for assessing state responsibility can be viewed as being guided by principles of judicial restraint; the ICJ commented as much as was necessary for it to adjudicate the case before it, while reserving judgment on the appropriateness of the ICTY's approach to the questions it faces. However, the Court's approach might also be understood as having been driven by purely pragmatic concerns that steered the Court away from upsetting already decided cases before the ICTY.

Those who are interested in establishing a framework through which to mitigate the potential problems arising from the fragmentation of international law are generally concerned with a lack of consistency between different international bodies. However, to the extent that the ICJ's approach to the question of the appropriate legal standard for assessing state responsibility in Bosnia v. Serbia was driven by pragmatic concerns, the case draws attention to the issue of jurisprudential consistency within different adjudicative bodies. Any attempt to standardize inter-courtrelations should be sufficiently flexible as to accommodate the - sometimes competing - need for intra-court jurisprudential consistency.

While the issues arising from the failure of one international court to defer to the previous judgments of another international court have been articulated at length in the academic literature, 95 our critique of the fact-finding approach taken by the ICJ in the Bosnia v. Serbia judgment suggests that scholars, judges, and litigants should perhaps be equally concerned about the potential problems arising from an inappropriate reliance on the findings of other courts. Furthermore, this is not a concern unique to the ICJ. The Pre-trial Chamber of the ICC recently relied on the ICJ's factual findings of the presence of Ugandan forces as an occupying power in Ituri ${ }^{96}$ in order to decide that, contrary to the charges presented by the prosecution, the nature of the conflict within which the alleged crimes took place was international, not non-international. ${ }^{7}$ As the case load of the ICC grows, one can predict the question of the circumstances under which it is appropriate for one international body to adopt the factual findings of another international body will become a significant issue for those interested in international criminal cases.

However, it is in terms of the implications for future applicants trying to establish state responsibility for genocide before the ICJ that the fact-finding approach taken

\footnotetext{
95. See supra note 4.

96. See Case Concerning Armed Activities on the Territory of the Congo (Democratic Republic of the Congo v. Uganda), Judgment of I9 December 2005, [2005] ICJ Rep., at para. 345.

97. See 'Décision sur la confirmation des charges', supra note 47 , at paras. $217,220$.
} 
by the Court in this case raises the most concerns. If one is to accept the Court's position that it has the ability and jurisdiction to make a positive finding of state responsibility for genocide, even in the absence of a genocide conviction for any individual perpetrator, ${ }^{98}$ then the Court should not use the absence of a genocide conviction to preclude it from finding that genocide was committed. ${ }^{99}$ If its factfinding approach in Bosnia v. Serbia is to set any precedent for how the ICJ will adjudicate future cases under the Genocide Convention, it is hard to see how the Court will ever make a positive genocide determination in the absence of a criminal court having already convicted individual perpetrators of genocide. On the basis of this case, the Court's approach seems to be that if another judicial body with jurisdiction over the events at issue has not already established genocide, the ICJ will not either. If this is correct, then the Bosnia v. Serbia judgment may have taken away with one hand what it has offered with the other - promising an international legal system that can hold states accountable for the commission of genocide, while simultaneously ensuring that in practice that promise will only rarely be fulfilled.

98. Bosnia v. Serbia, supra note I, at para. I82.

99. See supra section 3.I.I. 